Jarosław Wierzbiński

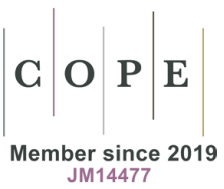

(iD) https://orcid.org/0000-0002-1351-4276

Uniwersytet Łódzki

Wydziat Filologiczny

Instytut Rusycystyki

Zaktad Językoznawstwa

90-236 Łódź, ul. Pomorska 171/173

jaroslaw.wierzbinski@uni.lodz.pl

\title{
Петр Червинский, Знак и значение. Семантика предсказаний в знамениях, повериях и приметах, Katowice: Wydawnictwo Uniwersytetu Śląskiego, 2020, ss. 240
}

\author{
Piotr Czerwiński, The sign and meaning. The prophecy semantics \\ in harbingers, beliefs and folk predictions, \\ Katowice: Wydawnictwo Uniwersytetu Śląskiego, 2020, pp. 240
}

\begin{abstract}
Резюме
Монография носит междисциплинарный характер, поскольку она совмещает вопросы когнитивной этнолингвистики, лингвистики культуры, социолингвистики, семантики, фольклористики, мифологии и рассматривает как вербальные, так и иконические коннотации и язык в магическом сознании. Предметом анализа в книге Петра Червиньского являются магические ритуалы, заклинания, сны и видения, а также семантика защитных атрибутов, то есть амулетов разного рода. Книга является ценным вкладом в исследования семиотической оценки пророчеств и народных гаданий. Это важное исследование как своей тематической оригинальностью, так и разнообразием анализируемого материала и его интерпретации.
\end{abstract}

\section{Summary}

The presented monograph is of an interdisciplinary nature, since it combines the issues of cognitive ethnolinguistics, cultural linguistics, sociolinguistics, cultural semantics, medieval studies,folklore, mythology and examines verbal and iconic connotations and language in magical consciousness. The subject of analysis in the book of Peter Czerwiński is magic rituals, spells, dreams and visions, as well as the semantics of protective attributes, that is, amulets of various kinds. The book is a valuable contribution to research into the semiotic evaluation of prophecy and folk fortune-telling. This is a valuable study both for its thematic originality and for the variety of analyzed material and its interpretation. 
Prezentowana monografia Piotra Czerwińskiego stanowi niezwykle inspirującą pozycję wydawniczą. Książka ma charakter interdyscyplinarny, ponieważ łączy w sobie zagadnienia z etnolingwistyki kognitywnej, lingwistyki kulturowej, socjolingwistyki, semantyki kulturowej, mediewistyki, folklorystyki, mitologii i traktuje o konotacjach werbalnych, ikonicznych oraz o języku w świadomości magicznej. Autor analizuje teksty nasycone przepowiedniami i odzwierciedlonymi w nich wróżbami, proroctwami, obrazami snów i znakami symbolicznymi. W kręgu owych tekstów znajdują się również paremie. Istotne jest odniesienie omawianych tekstów zarówno do określonej tradycji, jak i uwarunkowań kulturowo-mentalnych.

Tematyka monografii sama w sobie jest pasjonująca, co intrygująca zarazem, ponieważ traktuje o wieszczeniu o rzeczach mających nastąpić, o przepowiadaniu, przewidywaniu, czy też prognozowaniu przyszłych zdarzeń. Przepowiednie oparte są na odczytaniu przyszłości i zdarzeń z rozmaitych źródeł o rodowodzie biblijnym, astrologicznym, numerologicznym, apokaliptycznym, przy czym występują ich rozmaite interpretacje. Obiektem analiz w książce Piotra Czerwińskiego są obrzędy magiczne, zaklęcia, sny i widzenia, a także semantyka atrybutów obronnych, czyli amuletów różnego rodzaju.

Strukturę monografii tworzą zasadniczo trzy części/rozdziały obejmujące kolejno następujące zagadnienia: 1. О структуре предсказательных образов (Struktura przepowiedni); 2. Предсказание как экзистенциональный процесс (Przepowiednia jako proces egzystencjalny); 3. Мир человека как объект воздействия скрытыльх сил (Świat ludzki jako obiekt wpływu sił nieznanych/ wyższych/ukrytych).

Całość została opatrzona Przypisami (Примечания), które właściwie są szczegółowymi odsyłaczami/komentarzami i wyjaśnieniami omawianych kwestii wraz z wykazem bogatej literatury przedmiotu, czyli bibliografią. Pracę wieńczy wykaz wykorzystanych opracowań leksykograficznych oraz krótkie streszczenia w języku polskim i angielskim.

W rozdziale pierwszym O структуре предсказательных образов (s. 8-58) Autor odnosi się do symptomów, które zwiastują jakąś oczekiwaną nieuchronność, omawia przepowiednię w jej potencjale do materializowania się. Przedstawia czynniki zewnętrzne i wewnętrzne w projekcji przepowiedni. Nawiązuje przy tym do typologicznych różnic $\mathrm{w}$ semantyce kreowanych przepowiedni, do subiektów/podmiotów i ról w interakcjach oraz omawia emotywny charakter zachowań ludzkich.

Przepowiednie mają to do siebie, że ich semantyka nie ma ściśle jednoznacznego, konkretnego charakteru, jest ona raczej uogólniająca, co odnotowali tacy badacze, jak M. Kulkowa, M. Makarenkow, N. Fattachowa, T. Ziewachina, E. Tonkowa, A. Oropaj, Cz. Czintao, W. Stiegnij.

Piotr Czerwiński skrupulatnie śledzi najnowszą literaturę przedmiotu. Autor często prezentuje stanowisko innych badaczy, by na konkretnych przykła- 
dach wykazać różnice terminologiczne np. pomiędzy wierzeniami i wróżbami. Wg W. Charczenko i E. Tonkowej wyrażenie Ножницы держите сомкнутыми - не будет в доме ссор należy rozpatrywać jako wierzenie, natomiast jego transformacja Ножницы оставить открытыми - к ссоре staje się już wróżbą (zob. o tym w przypisie 2 na s. 223). Autor podziela stanowisko O. Christoforowej, że wierzenia determinują zachowania ludzi. Zgadza się też ze stanowiskiem N. Fattachowej, że właściwością przysłów i wróżb ludowych jest uogólniająca semantyka.

Rozdział drugi Предсказание как экзистенциональный процесс (s. 59187) jest najobszerniejszy pod względem analizowanych zagadnień. Autor docieka odpowiedzi w rozlicznych kwestiach, m.in. i takiej: co powoduje subiektem, co go skłania, by pewne stany, zjawiska i symptomy odbierać i interpretować jako znaki. Za przykład może posłużyć obrazowanie z Latopisu, gdzie ciemności, które ogarnęły wojów, jako efekt zaćmienia słońca, w interpretacji Igora zwiastują ich niechybną śmierć. Piotr Czerwiński analizuje adresatywny charakter wielu innych znaków zawartych w tych kronikach. Skupia się jednak na symbolice snu Światosława opisanego w ważniejszym zabytku literatury staroruskiej z okresu Rusi Kijowskiej „Słowie o wyprawie Igora”.

Widzenia senne relacjonuje Światosław. Przekaz Autora monografii na ten temat jest następujący: „Приснившийся Святославу сон, который он пересказывает затем своим боярам, наполнен образами несчастья, гибели и смерти. Первое, сразу же, - ночью с вечера одевали его черным саваном на кровати тисовой, что само по себе означает приготовление к положению в гроб. Но не о его, Святославовой, смерти, судя по всему, речь. И синее вино, с горем («съ трудомь») смешанное, и крупный жемчуг из пустых колчанов поганых толковин, и доски без князька в златоверхом тереме, и серые вороны, граявшие на лугу, после чего понесшиеся к синему морю, - все это знаки смерти. Вопрос только, чьей и какой, и почему именно в такой последовательности и в столь большом количестве?” (s. 61). Tak więc perły we śnie symbolizują łzy; zobaczyć dom bez belek konstrukcyjnych, na których osadzane są deski i krokwie dachowe (дом без князька) oznacza wielkie nieszczęście; widok kruków zwiastuje śmierć.

Dalej nie brakuje też kolejnych spostrzeżeń i sugestii na ten temat z uwzględnieniem również innych świadectw źródłowych zawierających ważny przekaz o śnie Światosława. Są zatem w rozważaniach semantycznych Piotra Czerwińskiego odesłania i do Sriezniewskiego i do D. Lichaczowa, a także M. Fasmera czy też dociekań etymologicznych P. Czernych. Źródłowy opis snu Autor dosłownie rozkłada na czynniki pierwsze i wyciąga z przeprowadzonej analizy stosowne wnioski. Rozpatruje semantykę wyrażeń синее море і синее вино (s. 65-67), by przekierować dalej analizę na symbolikę znaków i obrazów. Analizuje też przekaz bojarów o klęsce wojowników Igora i zwycięstwie Połowców. Podkreśla również przeciwstawienie tego co swoje i co obce. 
Uwaga skupia się następnie na zebranych przez Dala przysłowiach. Część $\mathrm{z}$ nich koresponduje z prowadzoną wcześniej analizą. Czerwiński rozpatruje z jednej strony paremie typu Кони ржут - к добру. / Галки и вороны, сидящие с криком перед домом, особенно утром, к худу. / Зеркало разбить - кхудy, z drugiej zaś takie jak: Аршина на кровать не класть - покойник будет. / Если невеста под венцом уронит платок, а жених поднимет, то скоро умрет. / Тринадиатый за стол не садится. / Троица троицей, а трех свечей на стол не ставят. Właśnie te drugie zakładają podejmowanie działań obronnych, bądź unikanie działań o niekorzystnym znaczeniu, czyli: Не класть (аршина на кровать); Не садиться либо Не сажать кого-то (тринадцатым, как тринадцатого, за стол); Не ставить (трех свечей на стол) (s. 74). Przegląd podobnych sytuacji kształtuje swoisty paradygmat nie tyle symbolicznych znaków i wierzeń, co zawartych w nich sensów.

Uchwycenie tych sensów nie jest ani proste ani jednoznaczne; często mają charakter implicytny. Zawarte w nich wróżby i przesądy niejednokrotnie wykraczają poza granice zwykłej bezpośredniej interpretacji i percepcji. Naprowadzają jednak na myśl, by czegoś nie robić lub działać w taki sposób, aby uniknąć nieprzyjemnych zdarzeń. Można w tym dostrzec pewien schemat czy model zachowania akceptowany przez daną społeczność, zgodnie z którym i przez który rozpoznaje ona i odróżnia swoje i własne od innego i obcego. Akceptowany jest zatem model pozytywny, natomiast jego przeciwieństwo nie zyskuje aprobaty i jest odrzucane przez ową społeczność. Poprzez taką interakcję, kontakt, czy też współdziałanie z czymś niewidzialnym i pozaziemskim jest rozpoznawane to, co własne, rodowe. Istnieje jakaś siła, która współpracuje z tą społecznością, którą można określić jako sacrum.

Czerwiński analizuje kolejne wróżby, które manifestują się w paremiach, m.in.: Перед дальней дорогой не мой волосы - беду накличешь. / Перед дальней дорогой надо подержаться за угол стола - это к удаче. / Если кто-то чужсй по твоим следам идет, то он забирает у тебя, впереди идущего, силу. / Незваный гость на двор - и беда на двор (s. 77). Kolejne trzy przykłady wskazują na to co robić lub czego nie należy robić, zaś ostatni wskazuje na zagrożenie, któremu można jakoś zapobiec, czy też je osłabić. Autor monografii wskazuje na szereg innych konotacji i możliwych rozstrzygnięć zdarzeń sygnalizowanych w paremiach.

Nadrzędny wątek tej części książki to jednak projekcja snu Światosława w relacji do ponadczasowości egzystencjalnej, a także liczne spostrzeżenia wróżbiarskie w aspekcie behawioralnym. Rozdział traktuje też o typologii semantycznej przepowiedni, zawiera rozważania o wilku, który przebiegł drogę i zawiera spostrzeżenia o semantyce w części interpretacyjnej, w której Autor odnosi się do interakcji z rzeczywistością, prezentuje czynniki czasowe i stałe w projekcji zachowań i osiąganych stanów. W tej części rozprawy Autor omawia specyfikę pożądanych/oczekiwanych działań, odnosząc się do rozmaitych okoliczności, w tym działań względem sił wrogich człowiekowi, jak biesy, diabły i demony. 
Rozdział trzeci Мир человека как объект воздействия скрытых сил (s. 189-217) traktuje o ingerencji tychże sił w egzystencjalnej przestrzeni człowieka i sposobom wyzwalania się z tej zależności. Autor inicjuje analizę w tej części pracy takim oto przykładem: Хлеб не выпекается, сырым остается - к разлуке или разорению (s. 189-190). Powstaje pytanie o jaką́s siłę fatalną, która powoduje, że chleb nie wypieka się jak należy. Nie to jest jednak przedmiotem analizy lecz więzi rodzinne, te egzystencjalne i emocjonalne, które są zagrożone w wyniku działania tej siły. Innego rodzaju przekaz wróżbiarski manifestuje się w powiedzeniu Не ешь во время учения: заешь выученное (s. 192-193). Nie tyle wiedza jest tu imperatywem, co adaptacja, przystosowanie do ogółu. Istotna jest myśl, że zostanie zmarnowana jakaś szansa. Jest tu przestroga przed utratą czegoś ważnego.

Specyficzne też treści kryje w sobie powiedzenie Ложку на столе после обеда забыть - к гостю (s. 194-196). Dotyczy ono sfery kontaktowej i to nie tyle czy tylko w odniesieniu do osób bliskich. Odnosi się do nieproszonego gościa i nie towarzyszy temu jakaś negatywna konotacja. Nie można przy tym wykluczyć, że jest to znak jakiejś ukrytej mocy, która powoduje, że łyżka zostaje zapomniana na stole. Ten znak można odczytać na rozmaite sposoby co prezentuje w swojej analizie Autor monografii. Istotne jest to, że oczekiwane przyjście gościa działa na domowników w ten sposób, że łyżka pozostaje. Taka sytuacja budzi niepokój i rodzi potencjalne zagrożenie.

Imponująca jest za każdym razem metodyczna argumentacja, którą proponuje Piotr Czerwiński. Jest to całe spektrum skojarzeń, przemyśleń i analiz, by wydobyć różne sensy, które przecież nie leżą na powierzchni, lecz trzeba je odczytać i przekonująco uzasadnić. Autor prezentuje różne projekcje bliskich relacji ludzkich posiłkując się przy tym ich wizualizacją w postaci tabelarycznego schematu co stanowi dobrą płaszczyznę syntetycznego obrazowania podjętej w książce tematyki. Swoje rozważania Autor zamyka perspektywą kontynuowania prac studyjnych na temat konceptualizacji świata, uwzględniającej przestrzeń semantyczną i semiotyczną słów, znaków i symboli.

$$
* * *
$$

Po tym przeglądzie, wybiórczym z konieczności, czas na podsumowanie i konkluzję. Znaczenie naukowe rozprawy Piotra Czerwińskiego Знак и значение. Семантика предсказаний в знамениях, повериях и приметах uwarunkowane jest ważną rolą czynników antropocentrycznych, psychologicznych w tym parapsychologicznych oraz parametrów socjologicznych we współczesnym językoznawstwie.

O wartości naukowej prezentowanej książki świadczą m.in. następujące cechy: 1. Wykorzystanie, opracowanie i usystematyzowanie licznych prac naukowych, 
odnoszących się do tematu rozprawy; 2. Dogłębność i wysoki poziom przeprowadzonej analizy językowej i kulturowej, a także umiejętność wieloaspektowego podejścia do problemu naukowego oraz interdyscyplinarnej interpretacji materiału badawczego, co jest zadaniem arcytrudnym; 3 . Autor zaprezentował spójny paradygmat kognitywny i kulturowy; 4. Rozprawa jest utrzymana w ścisłym stylu naukowym, czy wręcz w stylu naukowo-eksperymentalnym. 5. Narracja Autora jest oryginalna, uporządkowana i precyzyjna.

Oryginalność monografii polega głównie na tym, iż analizowane w niej zagadnienia w takim wymiarze nie były, bądź były tylko częściowo podejmowane przez badaczy. Poszczególne rozdziały monografii pozwalają na zapoznanie się $\mathrm{z}$ różnymi nurtami badawczymi w obrębie semantyki i symboliki przepowiedni w zwiastunach, wierzeniach i wróżbach ludowych. Nie sposób nie stwierdzić raz jeszcze dobitnie, iż problematyka w zaproponowanym przez Autora ujęciu nie była dotychczas przedmiotem całościowych, pogłębionych analiz.

Merytoryczny poziom przeprowadzonej analizy i interpretacji jest wysoki zarówno w warstwie teoretycznej poruszanych kwestii, jak i w zakresie praktycznego zastosowania metodologii badań, przynoszących interesujące i godne uwagi rezultaty. Praca wnosi wiele do wiedzy o znakach i ich symbolice oraz jej tendencjach rozwojowych. Trafność wyboru tematyki omawianej rozprawy jest poza wszelką dyskusją. Chciałbym podkreślić przy sposobności adekwatność tytułu monografii i jej śródtytułów do treści publikacji, w tym materiału ilustracyjnego.

Po lekturze monografii mam jednoznacznie pozytywną opinię o jej zawartości i walorach poznawczych. Stwierdzam z pełnym przekonaniem, że monografia Piotra Czerwińskiego pt. Знак и значение. Семантика предсказаний в знамениях, повериях и приметах stanowi cenny wkład w badania nad semiotycznym wartościowaniem przepowiedni i wróżb ludowych, dostarcza również szereg interesujących i ważnych w najnowszych badaniach informacji w zakresie analizowanych zjawisk. Aparat przypisów i odsyłaczy jest bogaty i pozwala umiejscowić rozważania na szerszym tle innych przywoływanych opracowań. Analiza przywoływanej literatury przedmiotu jednoznacznie potwierdza, że podnoszone w monografii zagadnienia zbadane zostały w kontekście aktualnego stanu badań. Na rynku wydawniczym nie ma podobnej publikacji z zaproponowanej przez Autora dziedziny. Jest zatem książka Piotra Czerwińskiego opracowaniem wartościowym zarówno ze względu na swą oryginalność tematyczną, jak i różnorodność materiału poddanego analizie i jego interpretację. 